\title{
SULA, A DARK LADY ${ }^{1}$
}

\author{
Manuela López Ramírez, IES. Alto Palancia, Segorbe (Castellón) \\ Email: lopez.ramirez.manuela@gmail.com
}

\begin{abstract}
Through Sula (the main character of Toni Morrison's eponymous novel), Morrison reinterprets the concept of the Dark Lady of the traditional Gothic romance. She is a demonic female, who defies the Law of the Father in her search for identity. As the embodiment of subversion, she becomes the "village witch", the symbolic expression of the African community's confrontation with evil. In fact, through Sula, Morrison reflects intensively on evil. The demonic female comes to be a scapegoat, the target of the black community's social frustrations. Sula is a modern Dark Lady with a radical power of self-creation and self-affirmation.
\end{abstract}

Key words: Dark Lady, Gothic, transgression, black community, evil, patriarchal

Título en español: Sula, una Mujer Oscura.

Resumen: A través de Sula (el personaje principal de la novela homónima de Toni Morrison), la autora reinterpreta el concepto de la Mujer Oscura del romance gótico tradicional. Ella es una mujer demoníaca, que desafía la Ley del Padre en su búsqueda de identidad; convirtiéndose en la "bruja del pueblo", símbolo de la confrontación de la comunidad africana con el mal. A través de Sula, Morrison reflexiona extensamente sobre el mal. La mujer demoníaca se convierte en el objetivo de las frustraciones sociales de la comunidad negra. Sula es una Mujer Oscura moderna con un poder radical de auto-creación y auto-definición.

Palabras clave: Mujer Oscura, Gótico, trasgresión, comunidad negra, mal, patriarcal

Balancing the frail, submissive paragon in early Gothic fiction is the dark, imperious, passion-ridden one, the femme fatale. She has independence of spirit, the emotional vibrancy, the ingenuity, and the moral fallibility [. . . but she pays a price for these strengths.

SYNDY CONGER, The Reconstruction of the Gothic Feminine Ideal in Emily Brontë's Wuthering Heights. The Female Gothic.

Despite white critics' reluctance to explore Toni Morrison's work from a white Western tradition like the Gothic, her novels can be examined according to what Linden Peach defines as a syncretist model, ${ }^{2}$ which advocates that African American writings be analyzed as culturally hybrid forms. Different critics, such as Mar Gallego, have emphasized Morrison's double consciousness: "Both elements-white and black, Western and African-combine to create a complete whole, sine qua non it is impossible to understand African American

Date of reception: 12 April 2012

Date of acceptance: 23 November 2012

2 Qtd. in Plasa: 8. Linden Peach 1995. Toni Morrison. Basingstoke and London: Macmillan: 11-12. 
literature" (2003: 14). ${ }^{3}$ In addition, some of the Gothic images and features have proved to be "unusually apt" for symbolizing the Black experience, while African Americans have used them to "produce cultural transformations so distinctive that they end up using the Gothic tradition to turn it on its head" (Hogle 2003: 215).

As many critics have argued, the Gothic has always held a strong appeal for women writers who, like Toni Morrison, focus on female and "feminine" values, as well as on their victimization in a patriarchal society, since this narrative mode addresses "the terrors lurking for women within patriarchal social arrangements" (Williams 1995: 7). The Gothic novel exposes females' discontent and need to rebel against the Law of the Father. Through the demonic woman, the idealized feminine status of the traditional domestic novel is questioned, cutting "across sentimental and traditional portraits of female life" (Gross 1989: 91). Dark Ladies expose the conflict over the female self: the ambivalence concerning the feminine roles of wife, mother or lover, and the discord over her sexuality. The Gothic is the perfect narrative mode to express women's cultural and social anxieties because it allows female authors to explore, from their position of "otherness", those aspects of their lives which had previously been unspeakable.

The Gothic is peopled with Dark Women who show their transforming demonic powers in their subversion of patriarchal rule. These passionate and independent females defy the Law of the Father in their identity quests: the "patriarchal laws of acceptability" (Grewal 1998: 48), which regulate their lives. They rebel against the social constraints that society imposes on them and question its definitions of womanhood. In Sula Morrison rewrites the figure of the Gothic subversive woman. Some strong similarities can be found between the Dark Lady of the traditional Gothic romance and Sula, the transgressive female of Morrison's African American fiction, and from these, I will focus, in this essay, on her search for identity and her rebelliousness in the face of patriarchal structures.

In her violation of social norms, Sula becomes the embodiment of subversion. She is characterized by the people of the Bottom as a typically transgressive figure, a witch: "Sula's personality, along with the snake-like birthmark that so intrigues those who encounter her, makes her the closest thing to a witch that the Bottom will ever have" (Harris 1991: 57). She becomes a scapegoat for her neighbors and suffers their accusations of witchcraft through her rejection of the Law of the Father. As a Dark Lady, Sula refuses to conform to the societal expectations and the socially-sanctioned gender roles of the black woman, questioning communal conceptions about the female, showing an independent and fearless personality. Her rebellious nature is revealed through her identification with the wild and ultimately with sex.

Like other Gothic heroines, Sula, who grows up without maternal love and guidance, is in search of her own identity. She fits Joanna Russ's description of the conventional Gothic lady, "young, orphaned, unloved, and lonely" (1983: 32). Sula, as Morrison says, is not "the run-of-the-mill average black woman" (Stepto 1994: 18). She is chiefly characterized by her wildness, her "asocial" behavior. For that reason she is not accepted in town. Affected by her grandmother's arrogance and her mother's negligence, she seems to grow up almost savagely. Sula is portrayed as a rebel in a number of ways. Morrison has said that she is

For more information, about the idea of double consciousness, see: Gallego: 14. 
interested in characters who are lawless in the sense that "They make up their lives, or they find out who they are" (Stepto 1994: 15). She associates this lawlessness with a kind of masculinity:

She [Sula] is a masculine character [...]. She will do the kind of things that normally only men do, which is why she's so strange. She really behaves like a man. She picks up a man, drops a man, the same way a man picks up a woman, drops a woman. And that's her thing. She's masculine in that sense. She's adventuresome, she trusts herself, she's not scared, she really ain't scared. And she is curious and will leave and try anything. So that kind of masculinity -and I mean in the pure sense- in a woman at that time is outrage, total outrage. She can't get away with that [. . .]. (1994: 27)

Sula's friend, Nel, believes that she should not behave like a man, since she is a black woman: "You can't be walking around all independent-like, doing whatever you like, taking what you want, leaving what you don't' (142). ${ }^{4}$

Sula starts showing her wild and rebellious character when she is only a child. She has the innate sense of adventure and curiosity of her age. Sula and Nel feel that they can "afford to abandon the ways of other people and concentrate on their own perceptions of things" (55). Sula refuses to be passive and allow some Irish boys to bully her and her friend Nel. Instead, she confronts them. She slashes off the tip of her finger with a knife and threatens them defiantly, "If I can do that to myself, what you suppose I'll do to you?" (54-55). In her asocial behavior, Sula takes after her mother and grandmother. Like Eva, who sets her own child on fire, Sula, Barbara Rigney argues, is also a "murderer", as is exemplified by her participation in Chicken Little's drowning and her passive pleasure in watching her mother burn. Moreover, Eva's sacrifice of her leg for insurance money parallels Sula's self-mutilation (1997: 64).

Sula, as a Dark Lady, claims her power of self-creation and self-affirmation. She explores her own thoughts and emotions, giving them full reign. For Sula, "There was only her own mood and whim" (121). As Morrison says, Sula is a New World black woman because "she's experimental. She's sort of an outlaw: she's not going to take it anymore. She's available to her own imagination. Other people's stories, other people's definitions are not hers. The thing about Sula is that she makes you do your own defining for yourself" (Moyers 1994: 269-270). Sula claims her own self: "I got my mind. And what goes on in it. Which is to say, I got me" (143). Sula believes that the other black women are like spiders whose only thought is their next ring of the web, more terrified of the free fall than the snake that might be lying in wait below. They are mere victims. However, the free fall required invention "and most of all a full surrender to the downward flight if they wished to taste their tongues or stay alive" (120). In contrast to the other females in the community, Sula dares to live a full life. Yet, her process of self-invention is thwarted, thus exemplifying what Gurleen

\footnotetext{
4 Morrison, T. 1973. Sula. New York: Alfred Knopf (all subsequent quotations from this edition will be identified by the page number included in parentheses in the text).

5 Morrison claims that "she is a much more contemporary woman than her time allowed her to be" (Koenen 1994: 67).
} 
Grewal calls "the social death of the woman": "the desire of Sula and Nel to experience the exhilaration of self-discovery" is frustrated (1998: 43).

As in Female Gothic fiction, Sula's asocial behavior is associated with her rejection of the conventional gender roles which women play in the community. The Peace females, Eva, Hannah and Sula do not conform to the image of the typical "good" black woman and contradict the stereotypes of the black female in African American fiction. They refuse to abide by traditional women's roles, which subordinate them. However, these roles, as Grewal argues, are enforced by the community "in the name of black solidarity and survival" and "any assertion of independence from the communal codes of conduct -especially by its women- is viewed with hostility", since it threatens self-preservation (1998: 44). ${ }^{6}$ Furthermore, Sula's willful transgressions of communal values are especially divisive because the black woman had historically been "the unifying force of a culture under siege" (Jennings 2008: 45).

Like the Gothic Dark Lady, Sula, with all her irrationality and creativity, has the imagination of an artist. Morrison suggests that if she had been engaged in an activity that had provided her with all she yearned for, she would not have been so restless or concerned with whim; "And like any artist with no art form, she became dangerous" (121). Sula has been described as "an active, destructive artist who, in the absence of 'paints, or clay' or a knowledge of 'dance, or strings' (121) makes human beings her adventure in life" (Harris 1991: 54). Deborah McDowell associates Sula's sexuality with creativity when the black woman creates a long poem while making love to Ajax and believes that, without art forms, Sula herself becomes her art work (1990: 156-157).

In Sula the connection between the Dark Lady and evil is very strong. As Morrison confesses in an interview to Danille Taylor-Guthrie, she is "certainly very much interested in the question of evil in Sula -in fact, that's what it was all about" (1994: 8). However, she focuses on a very different concept of evil, since blacks' cosmology is different from that of Western culture. For blacks, evil is an intrinsic part of human beings. In her representations of evil, such as Sula, Morrison subverts images of dominant Christianity and reflects diasporic retentions of West and Central African traditional cosmologies, which survived into the "collective (un) consciousness and culture of the United States" (Jennings 2008: 24). Some critics, such as Allen Alexander, argue that:

In Morrison's fictional world, God's characteristics are not limited to those represented by the traditional Western notion of the Trinity: Father, Son, and Holy Ghost. Instead, God possesses a fourth face, one that is an explanation of all those things -the existence of evil, the suffering of the innocent and the just- that seems so inexplicable in the face of a religious [Christian] tradition that preaches the omnipotence of a benevolent God. (qtd. in 2008: 27)

\footnotetext{
6 Trudier Harris also argues: "The peculiarly moral world view of African-Americans [. . .] has perhaps prevented the appearance of many female trickster figures" (characterized by their amoral behavior), such as Sula; "since women essentially held the group together during difficult periods of black history in America, to depict a female who stole, robbed, or killed would have had the effect of undermining the basic survival of the group" (1991: 72).

7 Jennings believes that in Sula, the existence of a fourth face or "evil dimension of God" is "rooted in the fusion of opposites [. . . ] the stabilizing balance of the fusion of good and evil", which "counters the Manichean
} 
Through Sula, the demonic woman, Morrison makes an extensive reflection on evil as another force in the universe. As a witch, she is a symbolic expression of the African community's confrontation with evil. Sula, as in traditional Gothic fiction, is marked in order to be recognized as a servant of the Devil. As in the case of many other Dark Ladies -such as Sethe in Beloved, or Elsie in Elsie Venner-, a distinctive feature of the demonic female is her eyes. Sula's "large quiet eyes" (52) represent the transgressive woman's self-assurance. Nevertheless, the physical mark that more clearly reflects her alliance with the Devil and defines her as a conjurer is the birthmark shaped rather like a stemmed rose, which crosses her face. Nel's husband thinks that Sula's smile "took some of the sting" from her blemish (104). The community sees how it identifies "her [as evil] from the very beginning" (114). They believe that the birthmark represented Hannah's ashes, "the sign of a murderer" (Jones \& Vinson 1994: online). They consider Sula a sorcerer: her blemish is, for them, "an indication of otherworldliness and use it to turn her into a witch" (62). Like the evil which Sula embodies, her skin stain becomes darker over the years: from its "blue-blade" color to a "scary black thing" (97), when she comes back from Nashville after ten years.

However, Sula's birthmark also comes to represent the Dark Lady's complex, fragmented and multiple identity and, as Barbara Rigney points out, it is "[ . . .] one of a series of marks, brands, or emblems that Morrison employs in most of her novels, not to 'distinguish' individuals, but (as blackness itself is a mark) to symbolize their participation in a greater entity, whether that is community or race or both. The marks are hieroglyphs, clues to a culture and a history more than to individual personality" (1997: 56). Sula's skin blemish is a complex and powerful symbol whose shape seems to be affected by her actions, as well as by other characters' perceptions. ${ }^{8}$ In fact, Morrison believes that it defines more those around her than Sula herself (Jones \& Vinson 1994: 181). Nel thinks it looks like a stemmed rose. Jude perceives it as a copperhead or a rattlesnake, and Shadrack likens it to a tadpole, "a sign of Sula's developing self" (Jones: online), since it has the shape of the fish that he loves. ${ }^{9}$ Despite all those interpretations, its evil nature seems to prevail:

[Sula's] birthmark metamorphoses from a photosynthesizing, air-producing, airaromatizing rose to a water-born but earthbound tadpole to an earth-crawling snake and, finally, to ashes, the aftermath of air consuming fire. The fourth interpretation, supplanting the other three, takes on an ominous malevolence since the ashes are evidence of misfortune that Sula allegedly causes. (Jennings 2008: 30)

Two events change Sula's life, triggering her anti-social behavior and the growth of evil inside her. First, one day she overhears her mother talking to her friends about the problems

dualistic indoctrination of absolute good and absolute evil, the separate and distinct binary of God and Evil" (2008: 26). Allen A. 1998. "The Fourth Face: The Image of God in Toni Morrison's The Bluest Eye”. African American Review 32.2, 193-303.

8 The same happens in Beloved: Sethe's scars are perceived very differently by the other characters, thus expressing their complex nature.

9 The tadpole is called fish, associated with water, when, in fact, the tadpole is a frog. Thus Morrison suggests that, like the rest of characters, Shadrack has his own interpretation of the birthmark and, consequently, of Sula's identity. 
of child rearing and discovers that, although her mother loves her, she does not really like her. ${ }^{10}$ Shortly afterwards, Sula, "in bewilderment", becomes "aware of a sting in her eye" (57), which is linked to the dark thoughts from which Nel pulls her away into the hot day. Both elements are associated with the psychic powers of the witch, the demonic woman. Secondly, one day down by the river, Sula and Nel are playing with Chicken Little. While Sula is swinging him around, he slips from her hands and ends up in the water, sinking without ever coming up. This is a horrific rite-of-passage, which, as Hortense Spillers writes, must remain secret: "the adult conscience of each springs forth in the eyes of the other, leaving childhood abruptly in its wake" (1990: 48). In her condition of "murderess", Sula becomes the ultimate demonic woman.

Following her mother's remarks and the boy's accidental death in the river, Sula changes. She starts to act up (her craziness), "fretting the deweys and meddling the newly married couple", which everybody took to be her nature coming out. It was difficult to deal with her "sulking and irritation" (74). Sula's wickedness is reflected horrifically in her passive, somewhat fascinated, behavior when she stands on the porch watching her mother burn. People are convinced that she is paralyzed, but her grandmother disagrees and thinks she is interested. Even if Sula is not involved in her mother's awful death, this event shows clearly her lack of concern for other people's lives. As Sula admits on her deathbed, "I never meant anything. I stood there watching her burn and was thrilled. I wanted her to keep on jerking like that, to keep on dancing" (147). Spillers traces Sula's behavior back to Chicken Little's accidental death and points to her "radical amorality" and, consequently, to her "radical freedom" (1990: 49).

Morrison's novel contains many omens, closely related to evil and frequently connected with Sula, which foreshadow death and adversity. Of these, one of the most important is her birthmark: "In many African cultures, a unique marking on a child often [. . . p presages some future event in which the child will participate" (Wilentz 1997: 131). It will foretell Sula's future betrayal of her friend as well as conjure up Hannah's death. Another omen, birds, announces Sula's arrival and signals the day of her return as an "evil day": "Accompanied by a plague of robins, Sula came back to Medallion. The little yambreasted shuddering birds were everywhere" (89). ${ }^{11}$ Even at Eva's house there are four dead robins on the walk, a presage of the forthcoming evil and death. Morrison wants the reader to get the awful feeling of those birds everywhere, to the point that Sula has to kick them aside to make her way through them, while suggesting that something is about to happen (Taylor-Guthrie 1994: 36).

Just after Sula comes back to Medallion, her next evil action takes place. She has a terrible argument with Eva and threatens to set her on fire one night when she is asleep. Finally, Sula gets her grandmother taken away to a nursing home for the elderly, which is run by the white church. When the people in the Bottom know about Eva being looked after by strangers, they really start to think that Sula is evil. Committing your elderly relatives

\footnotetext{
10 In Sula, Morrison also deals with two important themes of the Female Gothic: the ambivalence inherent in the mother/daughter relationship and woman's anxious approach to motherhood.

11 Trudier Harris states that these signs have their counterparts: in Hand, W. 1961, 1964. The Frank C. Brown Collection of North Carolina Folklore (vols. 6 and 7). Durham: Duke UP, sections on "portents", as related to future disastrous events (1991: 70).
} 
to a nursing home is, among African-Americans, especially abhorrent, since they strongly believe that ancestors should be honored and respected. Morrison insists: "We take care of them [old people] like they took care of us" (Parker 1994: 64). As Madhu Dubey argues, Sula shows "complete disregard for her ancestors", when she enjoys watching her mother burn and when she sends her grandmother away to a nursing home. Her "self-reliance is suicidal because it lacks a historical connection with the ancestor" (1997: 78).

In Sula, Morrison tries to depict a situation where there are so-called good people and so-called bad people, of whom Nel and Sula are symbolic. Nel is the kind of person who lives a good life, which for a woman at that time means taking care of children, being responsible, going to church, etc. Despite her limitations and lack of imagination or glamour, she carries the weight of the world. On the other hand, Sula is just the opposite, a rule-breaker, a transgressive female. As Morrison points out, "Nel knows and believes in all the laws of that community. She is the community. She lives in its values. Sula does not. She does not believe in any of those laws and breaks them all. Or ignores them" (Stepto 1994: 14). ${ }^{12}$ In Gothic fiction, Sula and Nel apparently stand for the two pairs of stereotyped antitheses of the concept of Woman, the angel/witch: the "two selves, the 'monstrous', passionate, sexual woman, and the 'good', rational, controlled woman" (Stein 1983: 127). ${ }^{13}$ However, the African American worldview is an alternative to the binary oppositions that can be easily found in Western discourse. Melville Herskovits argues that blacks have resisted the dichotomy "between good and evil in the realm of the supernatural, but [believe] that both are attributes of the same powers in terms of predisposition and control", a "characteristically" African worldview, which contrasts "vividly with the European habit of separating good and evil so strongly that the concept of the two as obverse and reverse of the same coin is almost non existent" (qtd. in Wilentz 1997: 132). ${ }^{14}$

Only in a very simplistic interpretation could Nel and Sula be regarded as good and evil respectively. They cannot be placed in "the gothically dichotomous worlds of 'good' and 'evil', but "occupying only relatively distant places on a moral continuum" (Grant 1988: 99). In fact, and despite appearances, the two friends are not so different. As Morrison writes, they complement each other: "if they had been one person, I suppose they would have been a marvelous person. But each one lacked something that the other one had" (Stepto 1994: 13). Morrison describes them as part of a single identity when she says that they are like a Janus' head (Parker 1994: 62).${ }^{15}$ Their strong friendship conforms to a typical Female Gothic theme, solidarity between women. Sula is characterized by powerful female alliances.

\footnotetext{
12 Morrison argues that, as far as Nel is concerned, "living totally by the law and surrendering completely to it without questioning anything sometimes makes it impossible to know anything about yourself" (Stepto 1994: 14).

13 Stein is referring to the two halves in which the self of the heroine of Jane Eyre is divided. Deborah McDowell says that "the definition of self becomes based on the community's 'absolute' moral categories about 'good' and 'bad' women [. . . . Nel is the color of 'wet sandpaper,' Sula is the 'heavy brown' (52), a distinction that can be read as patriarchy's conventional fair lady/dark woman, virgin/whore dichotomy, one reflected in Sula's and Nel's separate matrilineages" (1990: 155).

14 Herskovitx, M. 1941. The Myth of the Negro Past. Boston: Beacon.

15 In Roman mythology, Janus (or Ianus) was the god of gates, doors, doorways, beginnings and endings. He is most often depicted as having two faces or heads, facing in opposite directions. See: Grimal, P. 1996. The Dictionary of Classical Mythology. Malden, MA: Blackwell Publishing: 241.
} 
Sula is a transgressive femme fatale, a seductress and a temptress. She is considered a sort of "sex offender". Through her sexual drive, the demonic woman defies male rule, subverting the patriarchal system, as Claire Kahane states, "the female protagonist [. . .] penetrating forbidden spaces, testing the potentials of an identity and a sexuality outside the father's rule" (1983: 243). As a passionate creature, the Dark Woman is associated with unleashed sexual desire and her sexuality becomes the focus of males' fears: "the men are symbolically wounded by the women's sexuality" (Fleenor 1983: 21). Morrison's transgressive heroine oozes sensuality and expresses her sexuality quite openly. Sula can be compared to another famous witch of antiquity, Medea, who, as Julio Caro Baroja writes, "represents seduction; she is the archetype of the woman, who not only as a result of her art, but also because of her charm, because of her 'enchantment'-these words have a clear sexual meaning in their connection to Magic-, does what she wants with men" (2006: 46).

Along with the other women in her family, Sula loves men: "It was manlove that Eva bequeathed to her daughters [. . .]. The Peace women simply loved maleness, for its own sake" (41). Even though she is crippled, Eva has "a regular flock of gentleman callers" (41). She does not make love to them, but she has a great deal of fun in their company. Hannah, Sula's mother, cannot live without men. After her husband abandons her, she has numerous lovers; in fact, "She would fuck practically anything" (43). The women in the town cannot get along with her, since she would not think twice about sleeping with any of their husbands: her "expression of sexuality is unencumbered by marital laws and expectations" (Grewal 1998: 48). However, even if they do not like the way Hannah behaves, the females of the community can understand her: her actions are the result of sexual lust. And, as Morrison argues, "it was a compliment to know that somebody else wanted them [their husbands]. It was this quality that made her a perfectly charming person" (Parker 1994: 63). For that reason, when Hannah dies, they will come to her aid.

Sula discovers men through her mother who sometimes takes them to her bedroom, where her daughter also sleeps. On one occasion, she even finds Hannah in bed with one of her lovers. Observing her mother going into the pantry, where she often has sex, and coming out just the same only happier, Sula learns that sex is "pleasant and frequent, but otherwise unremarkable" (41). Sula finds fulfillment in lovemaking as a result of her need to assert herself in the sexual act. It seems ironic that, in the position of surrender, lying under someone, she can feel "her own abiding strength and limitless power" (123). For the transgressive female, sexuality is about self-affirmation and self-creation. As McDowell points out, Sula's sexuality, unlike Nel's, is "not attached to anything outside herself" or "expressed within the institution of marriage that legitimates it for women [. . .]. Rather it is in the realm of sensory experience and in the service of the self-exploration that leads to self-intimacy" (1990: 156).

The Dark Lady's ultimate transgression is frequently connected to her sexuality. Even though Morrison's women do not fall into the conventional Gothic categories of "Virgin/ Whore", Sula embodies "dangerous" sexuality because of the ease with which she has sex with men. The females of the Bottom cannot forgive Sula, as they did with her mother, Hannah, for sleeping with their husbands since her actions are not the result of love or lust. They cannot see her behavior as a way of "complimenting" them (115) on their good taste, and consider her as "sexual experimenter", who, after lovemaking, discards her lovers 
since "none measures up to whatever undefined standard she uses for judgment" (Harris 1991: 77). While Hannah's and Eva's unleashed sexuality "came out of compassion or some human feeling. Sula's behavior looks inhuman, because she has cut herself off from responsibility to anyone other than herself' (Koenen 1994: 68). For the black community, the fact that Sula has sex with her neighbors' and friends' husbands is unacceptable, but sleeping with her best friend's husband and then dumping him for others is unforgivable. Nobody seems to understand why Sula has sex with Jude. However, her actions may appear acceptable from an African American perspective, since, as Wilentz reminds us, in contrast to Western communities which stress heterosexual relationships, African-based societies emphasize consanguineal relations, and "significant others", such as friends, over conjugal relations (1997: 132).

Nevertheless, it is as a result of her interracial sexual transgressions that Sula oversteps the limits that the community can tolerate. The black community accuses Sula of being a witch, a demonic woman, because she is believed to have sex with white males: "that is the ultimate sign of deviation from their norm, and it puts Sula in league with all manner of strange beings" (Harris 1991: 62). In a patriarchal society, black males cannot condone black females' interracial sex, even if they would not think twice about sleeping with white women. It is unthinkable that a black female would go willingly to bed with a white man unless it was a case of rape. Black women must submit themselves to male rule: "Male sexual antagonism and male subjection of the female play a major psychological role in the Bottom's indictment of Sula as morally evil" (Jennings 2008: 49).

The Gothic focuses on "abnormal" sexuality. As many critics have pointed out, there are lesbian resonances in Sula's relationship with Nel. Morrison emphasizes the solidarity and friendship between women, in contrast to the male-female relationship that is at the core of the hetero-patriarchal society. Sula and Nel have been very close since their childhood, united by their similar backgrounds "distant mothers and incomprehensible fathers (Sula's because he was dead; Nel's because he wasn't)" (52). As a child, Sula discovers that she and $\mathrm{Nel}$ are neither white nor male and, consequently, "freedom and triumph was forbidden to them" (52). The revelation creates a special bond between them. They share many important experiences as well as providing for each other's needs. As Nel says, "Talking to Sula had always been a conversation with herself" (95). Sula makes her friend grow and makes her fulfilled, and vice versa.

However, when Nel engages in a heterosexual relationship and marries, Sula leaves town. In Compulsory Heterosexuality and Lesbian Existence, Adrienne Rich explains how "lesbian" relationships between girls end when they begin going out with boys and, later, marry them. Rich writes, quoting Kathleen Barry, that, at that moment, the young girl's associations with female friends "become secondary to her" and "her own identity also assumes a secondary role and she grows into male identification" (1980: 645). It is not until the end of the novel that Nel discovers that her ties with Sula have been much more important to her than the connection she had with her husband. Nel's relationship with Jude impairs the development of her identity, while her "lesbian" bond with Sula fulfills her. Thus, Sula's friendship with Nel unveils what Rich calls "the lesbian continuum", which "embrace many more forms of primary intensity between and among women, including the sharing of a rich inner life" (1980: 648-649). As many critics, among them Dubey, have 
argued, in Sula, the importance of the heterosexual relationship is displaced by female bonding, which does not fuse its members into one as in a man-female couple, but which helps each one to grow (1997: 73).

The Gothic exposes the role conflict women face in the domestic sphere, criticizing the institutions of heterosexuality and reproduction. Sula expresses her refusal to perform the traditional roles of her gender. ${ }^{16}$ Unlike the rest of the females in the black community, she is not interested in settling down with a man and starting a family. She wants to stay by herself, as she tells her grandmother: "I don't want to make somebody else. I want to make myself" (92). Sula feels like a completely free human being, despite the fact that she does not have any sentimental attachments or responsibilities in her life. In her conversation with $\mathrm{Nel}$, when she is bed-ridden, Sula expresses her conviction that life is not about keeping a man. Morrison associates heterosexuality not just with loss, but also with death as Sula states, in her observations about the women in her community, that "those with husbands had folded themselves into starched coffins" (122). As McDowell writes, "Like so many women writers, Morrison equates marriage with the death of the female self and imagination" (1990: 154). The Dark Lady's extreme sexual passion is considered dangerous because it constitutes a threat to patriarchal institutions, especially heterosexual relationships and the family, but also to motherhood. That is why, as Barbara Christian concludes, she becomes the demonic female: "Since she [Sula] does not fit the image of mother, the loose woman, or the lady-wife [. . .] the community relegates her to their other category for woman, that of the witch, the evil conjure woman who is part of the evil forces of Nature" (qtd. in Galehouse 2010: online). ${ }^{17}$

Sula, as a rebellious modern female, can only truly desire a permanent heterosexual relationship in which both man and woman can relate at the same level. Before she met Ajax, Sula had had many lovers, but none provided her with reciprocity. Ajax does not consider or treat her as a woman, as an inferior human being. He listens to her and does not baby her or protect her. He is interested in what she thinks and expects "brilliance from her" (128). Ajax acknowledges her toughness and wisdom and expresses his comfort in her presence. Unlike Jude, who absorbs Nel into himself, Ajax "is the potential of a profound comradeship" (Grewal 1998: 54). As Morrison points out, he "was the one man she could relate to on that level that would make her want something she had never been interested in before, which was a permanent relationship [. . .]. He treated her as a whole person, not as an extension of himself" (Stepto 1994: 18).

According to Nina Nichols, demonic Gothic females suffer "spiritual penalties of alienation, isolation, madness and eventual death". They, as orphans, are "emotional outsiders", and "the costs of this romantic condition" are "deprivation and ostracism" (1983: 191). Rebelliousness and difference are at the core of their aloofness. Sula is a true outcast, whose alienation seems to start after Chicken Little's accidental death. As some critics have

\footnotetext{
16 On different occasions, as in Tar Baby, Morrison has criticized the modern black woman's social position, which excludes the connection with the female community because it considers traditional black womanhood old-fashioned and its roles unfulfilling. Thus contemporary "liberated" women, such as Sula, usually return to the community or are haunted by a feeling of betrayal of the black females' cultural values and traditions, as is Jadine (Denard 1988: 175).

17 Christian, B. 1985. Black Feminist Criticism-Perspectives on Black Women Writers. New York: Pergamon.
} 
argued, it is the consequence of her reaction to this event: Trudier Harris (1991) emphasizes Sula's refusal to confess or ask for forgiveness, while Carolyn Jones (1993) highlights her refusal to remember and mourn. The fact is that Sula does not come to terms with her actions, which causes her to become detached from her community. Thus, as Jones states, she re-enacts the Cain story and becomes a victim and a victimizer: Sula's is "the symbol story of the [rejected, guilty] human soul" (qtd. in Jones 1993: online). ${ }^{18}$

However, unlike other Gothic females, Sula seems to accept her isolation willingly: Morrison "creates one of the few black women heroines to deliberately embrace the role of a pariah" (McKay 1988: 4). Sula is, in fact, a self-reliant woman, who belongs to a "household of independent women" (48). She shows her assurance and confidence by ignoring the counter-conjuring and gossiping of the people of the Bottom. Her behavior makes the community watch her more closely than they do the other "bitches" or "roaches" in the town and, as Harris asserts, they "label her difference [Sula's] as witchery and thereby justify shunning her" (1991: 63). Thus Sula's isolation is associated with her transgressive nature and with her inability to relate to other people. ${ }^{19}$ Sula's only true connection with another human being is her friendship with $\mathrm{Nel}$ and then, for a short period, with Ajax. She does not really care for other people and that is why she can commit her grandmother to an institution. The terrible plight of a free spirit like Sula, who does not fit a conventional role, is that she cannot be part of society, nor can she live outside it. However, on the other hand, it is ostracism which allows the demonic female to write her own story, for which Sula pays a high price.

In Sula, Morrison focuses on how black people experience evil. African Americans, Morrison says, do not respond to evil in the same way as whites, whose "reaction to something that is alien to them is to destroy it" (Taylor-Guthrie 1994: 8). Nevertheless, blacks believe that evil is part of our universe. That is why the black community in the Bottom accepts pariahs: "Outlaws of both African and European descents who have committed censurable moral evil, crimes that injure others, commonly live in Black neighborhoods as anonymous, undocumented social exiles in order to evade capture and (re-incarceration)" (Jennings 2008: 7). They have the Deweys, Shadrack and Sula, who "are all variations of the pariah" (Tate 1994: 169). Blacks never try to prevent evil from happening, destroy it or change it in any way. Despite their fear, they accept the evil forces of nature. They think that it is their purpose to overcome them. Stoning sinners, like committing suicide, is beneath them. Morrison states: "Blacks never annihilate evil. They don't run it out of their neighborhoods, chop it, or burn it up. They don't have witch hangings. They try to protect themselves from evil, of course, but they don't have that puritanical thing which says if you see a witch, then burn it, or if you see something, then kill it" (Taylor-Guthrie 1994: 8).

From the moment the people of the Bottom regard Sula as a witch, a demonic woman, they start protecting themselves from her, but they do not get "surprised at its existence or horrified or outraged" (Parker 1994: 62). They call her names, but they do not hurt her. They "laid broomsticks across their doors at night and sprinkled salt on porch steps" (113). They also try to "collect the dust from her footsteps", maybe, as Harris points out, to use

18 Quote taken from John Steinbeck's East of Eden. New York: Bantam, 1952: 240.

19 According to Elizabeth B. House, Morrison gives the name of a food to Sula, Shad and Plum. However, the nurturing qualities that their names suggest are thwarted (1997: 104). 
it as a potion against her (1991: 57). And yet, they accept her. In a way, as Morrison says, the black community is quite protective towards Sula, since there is no other place where she could have lived without being harmed:

[...] in its ability to contain contradictions, the community provides for her [Sula] [...] the only place that will accept her and the only home she will ever know. Her wanderings away from the Bottom can only bring her full circle [. . .] back to it, for it is able to absorb if not to condone her 'otherness,' and it gives her the identity that locks her both inside and outside the community's folk traditions. People in the community grant to her the power she has and she accommodates them by living out their fantasies of otherness. (1991: 57)

The traditional Dark Lady is frequently associated with the supernatural. She is believed to possess evil magic powers and, because of them, she may become a destructive force. Sula responds to Gábor Klaniczay and Éva Pócs' definition of the "neighborhood witch" or "social witch", for which "the basis of witchcraft accusations is envy between the neighbors" (2008: 305). In her role as a witch, Sula exposes the Gothic alliance between the dark heroine and the demonic or supernatural realm. Sula is thought to possess psychic powers, which could be used to hurt other people. As Jennings writes, sorcerers neither learn nor are aware of them; their sheer proximity may produce evil and their malefic powers would affect family and community members: "Sula's mere presence in the Bottom; her close, physical proximity when disaster and death occur; and her impulsive psychic leanings, which damage relationships and disrupt social order, position her squarely in the malevolent role" (2008: 37). ${ }^{20}$

The black people of the Bottom accuse Sula of all manner of evildoing and tell many stories about her, such as how she pushes little Teapot, a five-year-old child, down the steps, when in fact he falls accidentally. Another story is about Mr. Finley, who chokes on a chicken bone and dies when he looks at Sula. Other pieces of evidence which they consider are: the fact that she does not look her age; that she has not suffered from any childhood diseases and that she has shown no normal signs of vulnerability. In addition, Dessie, "who was a big Daughter Elk and knew things", reveals to her friends, "the most damning evidence" of Sula's witchery (115): she had seen Shadrack, who was not civil to anyone, paying his respect to Sula, and Sula had smiled at him, when she looked hatefully at everyone else. Consequently, as Harris writes, "The community also judges Sula to be in league with the devil [...] Dessie [. . .] is convinced that she is witnessing a greeting between two of Satan's disciples" (1991: 64).

Apart from Nel or Ajax, Shadrack is the closest thing to a friend that Sula has in her life. If there is a quality that Sula shares with Shadrack, it is, as Morrison says, their marginality: "Sula as (feminine) solubility and Shadrack's (male) fixative are two extreme ways of dealing with displacement" (1990: 223). Sula first meets the insane veteran when she unintentionally kills Chicken Little. This encounter connects her "crime" with the presence of death, which the deranged figure comes to represent. According to Maggie Galehouse,

\footnotetext{
20 Other "witch-like" women created by Morrison, such as Pilate, Circe and Thérèse, also have unearthly
} abilities. 
both Sula and Shadrack are first-hand witnesses of death and, perhaps as a result of their experiences, "both face their mortality and the precarious construction of the self in direct, disturbing ways" (2010: online). No sooner do they meet than an unbreakable bond seems to have been established between the two pariahs. Shadrack views Sula as visitor, company, guest, social life, woman, daughter and friend.

Morrison emphasizes the different ways in which the community treats Sula, the demonic woman, and Shadrack, despite the fact that they are both outlaws and connected to evil. For the people of the Bottom, it is much easier to accept Shadrack than Sula "because he's systematized. They know what to expect from him" (Tate 1994: 169). He is much more easily integrated in the community because he does not pose any threat to their identity or order. His madness can be assimilated, without any problems, as part of their daily routine. According to Morrison, Shadrack is trying to establish some order in what he considers a disorganized world and people can understand his way of organizing chaos in the celebration of the National Suicide Day (Stepto 1994: 22). However, the members of the black community see Sula's rejection of their social conventions as a menace. Her refusal to accept the patriarchal order seems to jeopardize the social fabric of Medallion. As Cedric Bryant argues, Shadrack is less threatening because he is "assigned a place in the community's life" (qtd. in Galehouse 2010: online), ${ }^{21}$ whereas the demonic female cannot be part of it.

The people of the Bottom attribute all evil to Sula, who "becomes the measure of evil for the community, their catch-all explanation for natural and unnatural occurrences, their chance to triumph, day after day, over the devil in their midst" (64). Even though she seems to disrupt the social system, Sula is just the product of the tensions felt by the black community at a time in which it struggles to define itself after the recent period of slavery, when Medallion is still a community "bound in hate" (Jones 1993: online). As Caro Baroja highlights, "Witchcraft [. . .] increases in situations of distress, natural catastrophes; when the existence of human beings is not controlled by individual passions, but by communal miseries. They are blamed for all the ills of our society" $(2006: 111,314) .{ }^{22}$

The black community concentrates its social and economic frustrations, thwarted aspirations and suppressed hopes on the demonic woman, who becomes a scapegoat. As Grant argues, "The black community of the Bottom releases some of its uneasiness by classifying, and thus standardizing, her [Sula] as 'evil'"(1988: 92). ${ }^{23}$ Morrison shows how the community benefits from the fact that "Anger at the economic structure that keeps them down is vented on an enemy within, who appears to threaten a precariously functioning world. By heaping their anger on Sula, the community channels its deep frustration within its own bounds" (Grewal 1998: 45). Even though it may seem ironic, having such evil

\footnotetext{
${ }^{21}$ Galehouse believes that Shadrack's character helps define Sula as the "new world woman". It is the contrast that confirms Sula as "neither mad nor asocial" (2010: online). Bryant, C. 1990 "The Orderliness of Disorder: Madness and Evil in Toni Morrison's Sula”. Black American Literature Forum 24, 31-45.

22 Caro Baroja (2006) is writing about witchcraft in Europe from the 14th century onwards. In the last line, he is comparing witches with politicians (314).

23 Magdalena Vallejo Álvarez also emphasizes how the black woman is victimized by a community that suffers the violence of the dominant white society. The stigmatized and ostracized figure of Sula is the evil the community fights against (353).
} 
in their midst makes the community better. Scapegoats are very useful for the blacks of Medallion, since they use them for their improvement as human beings:

Their [the community's] conviction of Sula's evil changed them in accountable yet mysterious ways. Once the source of their misfortune was identified, they had leave to protect and love one another. They began to cherish their husbands and wives protect their children, repair their homes and in general band together against the devil in their midst. (117-118)

In spite of the fact that Sula apparently seems to be the embodiment of evil, Morrison shows us the ambivalence of this representation. As Morrison writes, "one can never really define good and evil. Sometimes good looks like evil; sometimes evil looks like good-you never really know what it is. It depends on what uses you put it to. Evil is as useful as good is, although good is generally more interesting" (Stepto 1994: 14). Actually, Sula is not much worse than her grandmother or mother were before her. Her grandmother, in her godlike stance, had killed her own son, even if she had done it out of concern for his welfare. Eva believes that his life is not worth living, but, at the same time, she acts selfishly, since she cannot stand it any longer. Hannah, on the other hand, is a negligent mother who will sleep with any man, regardless of her neighbors' or friends' feelings.

Even Sula's friend, Nel, is not as virtuous as she seems. It is not until the end of the story that we understand her hypocritical complicity in Chicken Little's drowning. Grant considers that Nel "may be as "evil"” as Sula, or even more so, as a result of the hypocrisy involved in her "voyeuristic complicity" in the little boy's death (1988: 101). On the other hand, Nel has always blamed Sula for having sex with her husband. When Sula is dying, Nel visits her and asks her about the reasons she had to sleep with her husband. Then Nel realizes that Sula would not know what to answer, since she cannot tell right from wrong. Moreover, Sula's concept of friendship is different. She regards Nel as "the closest thing to both an other and a self" (119). Sula has sex with Jude because they have always shared everything. Besides, Nel had always accepted all aspects of Sula. And yet, now, Nel belongs to the town and its ways, and behaves the way others do. Their lives go in completely and irrevocably different directions. When Nel is about to leave, Sula asks her friend how she knows that she was the one who was good. Sula, as McDowell says, "is an ambiguous character with a repertoire of responses along a continuum and thus cannot be defined as either totally 'good' or 'bad"' (1990: 157).

The terrible ostracism of Sula, the Dark Lady, within her community is shown in the way the blacks respond to her death. When Sula dies, they do not stop working and go to collect her body, which they did even for the worst prostitute in town. Her dead body stays in Eva's bed the whole day until Nel calls the hospital and the white people take care of the corpse. The blacks only go into the cemetery to sing, once the gravediggers leave the place where "the most magnificent hatred they had ever known" finally lies (173). They only gather to sing at Sula's funeral to uphold a tradition, not out of respect as in other burials. The people of the community do not believe that she will cross the Jordan as the lyrics say, but they "congratulate themselves for being generous even to one of the devil's disciples" (Harris 1991: 84). The inexplicable reasons for Sula's death may point to a sort of punishment from heaven for her witchcraft and evil ways. However, as Dubey argues, 
she does not feel the shame or contrition of her literary predecessors; "she dies proudly" (1997: 74), believing that her death is better than that of other women: "I know what every Black woman in this country is doing. Dying. Just like me. But the difference is, they dying like a stump. Me, I'm going down like one of those redwoods" (143).

Sula's death seems to bring a brighter day. At the beginning, there are signs that foretell a sunny future. First, the rumor that the tunnel would use black workers becomes an announcement. After so many years it looks as if, finally, the government is going to extend employment to black men. Then the renovation of the old people's home, to which Eva is to be transferred, is regarded as "a clear sign of the mystery of God's ways, His mighty thumb having been seen at Sula's throat" (151). However, these are merely illusory signs of hope. Blacks will soon realize that, with Sula's death, evil has not vanished from their world. In November Medallion turns silver, announcing, in an apocalyptic way, the beginning of trouble. It starts to rain as "if the world were coming to an end" (152). The late harvest is ruined and fowl die. This seems like a plague sent by God himself. The chilly weather makes poor people sick and hungry. The general relief that Sula's death produces is followed by a growing restless irritability. There is no reason to make an effort to be better people any more: mothers start to neglect their offspring, since they do not have to defend them against "Sula's malevolence" (153); daughters begin to express resentment towards their elderly relatives; wives stop catering to their husbands' needs.

In 1941, a year after Sula's death, the black community join the National Suicide Day procession and when the crowd reach "the tunnel they were forbidden to build" (161), it becomes clear that Sula is not their real problem. Their silenced hope and unfulfilled desires have lain on that unfinished tunnel all along. Black men could have earned a living there in Medallion, instead of having to leave town to work in the steel mills in Akron and Lake Erie. The National Suicide Day parade ends tragically. Many of the people of the Bottom are drowned in the tunnel, buried by their frustrations and false hopes, or maybe, as Carolyn Jones states, "destroyed by the angry spirit of the dead Sula" (1993: online).

To sum up, in the character of Sula, Morrison reinterprets the powerful myth of the Dark Lady of the conventional Gothic novel. She revives a tradition that focuses on the female and "feminine" values, which have been debased. Through the demonic woman, Morrison explores the disturbed Gothic female self, the ultimate Other, while unveiling her constraints in a patriarchal society. At the core of her transgressiveness is her defiance of the Law of the Father and her non-compliance with the communally-sanctioned ways. Morrison shows women's dissatisfaction with the patriarchal arrangements in the demonic female's rejection of her traditional gender roles and values, thus questioning social definitions of femininity. The Dark Lady highlights the limits that the patriarchal society sets for the female identity.

The danger symbolized by the Dark Lady's sexuality is closely tied to the patriarchal paradigm, since it violates socially- and morally-sanctioned codes and threatens patriarchal institutions, especially marriage and the family. Through her demonic woman, Sula, Morrison questions gender relationships, heterosexuality, while emphasizing women's sisterhood. The transgressive female does not conform to the standard "good" black woman, but, on the contrary, "deconstructs the hierarchies of good and evil, right and wrong" (Galehouse 2010: online). That is why Sula becomes the "village witch", the target of the 
black community's social frustrations and the symbol of its confrontation with evil. Despite her demonic powers, the rebellious woman is vulnerable in the patriarchal society. The society is not ready for the transforming powers of the Dark Lady who, as in traditional Gothic, is first repudiated, then ostracized and, finally, annihilated.

Sula is a modern Dark Lady who invents herself, giving unlimited freedom to her feelings and thoughts, a woman who takes her power of self-creation and self-affirmation to the limit: "She [Sula] is a new world black and new world woman extracting choice from choicelessness, responding inventively to found things. Improvisational. Daring, disruptive, imaginative, modern, out-of-the-house, outlawed, unpolicing, uncontained, and uncontainable. A dangerously female" (Morrison 1990: 223). As a Dark Lady, Sula is the $20^{\text {th }}$ century self-made African American woman who dares to resist and challenge the social arrangements of oppressive male rule, symbolizing the female black self's quest in the patriarchal society. Through Sula, Morrison gives an alternative version of black experience and of American identity and history.

\section{REFERENCES}

CARo Baroja, J. 2006. Las brujas y su mundo. Madrid: Alianza Editorial.

CONGER, S. 1983. "The Reconstruction of the Gothic Feminine Ideal in Emily Brontë's Wuthering Heights.” The Female Gothic. Ed. J. FleEnOR. Montreal: Eden. 91106.

Denard, C. C. 1988. "The Convergence of Feminism and Ethnicity in the Fiction of Toni Morrison." Critical Essays on Toni Morrison. Ed. N. McKay. Boston: G. K. Hall \& Co.. 171-179.

Dubey, M. 1997. “"No Bottom and No Top': Oppositions in Sula.” Toni Morrison: Contemporary Critical Essays. Ed. L. PEACH. New York, NY: St. Martin's. 70-88.

FLEenOR, J., ed. 1983. The Female Gothic. Montreal: Eden.

Galehouse, M. 2010. “'New World Woman': Toni Morrison's Sula.” Papers on Language and Literature. 5 Jul. 2010.

http://www.findarticles/p/articles/mi_qa3708/is_199910/ai_n8871625/

Gallego Durán, M. 2003. Passing Novels in the Harlem Renaissance: Identity, Politics and Textual Strategies. Hamburg: Lit Verlag.

Grant, R. 1988. "Absence into Presence: The Thematics of Memory and 'Missing' Subjects in Toni Morrison's Sula.” Critical Essays on Toni Morrison. Ed. N. McKaY. Boston: G. K. Hall \& Co. 90-103.

Grewal, G. 1998. Circles of Sorrow, Lines of Struggle: The Novels of Toni Morrison. Louisiana: Louisiana State UP.

Gross, L. 1989. Redefining the American Gothic: from Wieland to Day of the Dead (Studies in Speculative Fiction, No 20). London: UMI Research Press (Ann Arbor). 
HARris, T. 1991. Fiction and Folklore: The Novels of Toni Morrison. Knoxville, TN: Tennessee UP.

House, E. 1997. "Imagery, Figurative Language, and Symbols.” Approaches to Teaching the Novels of Toni Morrison. Eds. N. MCKAY \& K. EARLE. New York, NY: MLA. 99-105.

Hogle, J. 2003. "Teaching the African American Gothic: From its Multiple Sources to Linden Hills and Beloved." Approaches to Teaching Gothic Fiction: The British and American Traditions. Eds. D. Hoeveler and T. Heller. New York: MLA. 215-222.

Jennings, La V. 2008. Toni Morrison and the Idea of Africa. Cambridge: Cambridge UP.

Jones, B. \& Vinson, A. 1994. “A Conversation with Toni Morrison.” Conversations with Toni Morrison. Ed. D. TAYLOR-Guthrie. Jackson: Mississippi UP. 171-187.

Jones, C. 1993. "Sula and Beloved: Images of Cain in the Novels of Toni Morrison." African American Review 27.4. 24 Jul. 2007.

http://www.geocities.com/tarbaby2007/beloved2.html

Kahane, C. 1983. "The Maternal Legacy: The Grotesque Tradition in Flannery O'Connor's Female Gothic.” The Female Gothic. Ed. J. FleENOR. Montreal: Eden. 242-256.

Klaniczay, G. \& Pócs, É. 2008. Witchcraft, Mythologies and Persecutions (Demons, Spirits, Witches; vol. 3). Budapest \& New York: Central European UP.

Koenen, A. 1994. "The One Out of Sequence." Conversations with Toni Morrison. Ed. D. TAYLOR-GuTHRIE. Jackson: Mississippi UP. 67-83.

McDowell, D. 1990. “"The Self and the Other': Reading Toni Morrison's Sula and the Black Female Text." Modern Critical Views Toni Morrison. Ed. H. BLOom. New York and Philadelphia: Chelsea House Publishers. 149-164.

McKay, N., ed. 1988. Critical Essays on Toni Morrison. McKay. Boston: G. K. Hall $\&$ Co.

McKay, N. \& Earle, K., eds. 1997. Approaches to Teaching the Novels of Toni Morrison. New York, NY: MLA.

Morrison, T. 1973. Sula. New York: Alfred Knopf.

_. 1990. "Unspeakable Things Unspoken: The Afro-American Presence in American Literature.” Modern Critical Views: Toni Morrison. Ed. H. Bloom. New York and Philadelphia: Chelsea House Publishers. 201-230.

Moyers, B. 1994. "A Conversation with Toni Morrison.” Conversations with Toni Morrison. Ed. D. TAYLOR-GUTHRIE. Jackson: Mississippi UP. 262-274.

Nichols, N. 1983. "Place and Eros in Radcliffe, Lewis, and Brontë." The Female Gothic. Ed. J. FLEENOR. Montreal: Eden. 187-206. 
PARKer, B. 1994. “Complexity: Toni Morrison's Women.” Conversations with Toni Morrison. Ed. D. TAYLOR-GUTHRIE. Jackson: Mississippi UP. 60-66.

Plasa, C., ed. 1998. Toni Morrison: Beloved. Columbia Critical Guides. New York: Columbia UP.

Rich, A. 1980. "Compulsory Heterosexuality and Lesbian Existence." Signs. Vol. 5, No. 4. Women: Sex and Sexuality. Chicago UP: 631-660. 6 May 2011.

http://educ.jmu.edu/ brysonbp/367/RichCompulsuryHet.pdf

Rigney, B. 1997. "Hagar's Mirror: Self and Identity in Morrison's Fiction." Toni Morrison: Contemporary Critical Essays. Ed. L. PEACH. New York, NY: St. Martin’s. 52-69.

Russ, J. 1983. "Somebody's Trying to Kill Me, and I Think It's My Husband: The Modern Gothic." The Female Gothic. Ed. J. FleENOR. Montreal: Eden. 31-56.

SPILlers, H. 1990. “A Hateful Passion, a Lost Love.” Modern Critical Views: Toni Morrison. Ed. H. Bloom. New York and Philadelphia: Chelsea House Publishers. $55-84$.

Stein, K. 1983. "Monsters and Madwomen: Changing Female Gothic." The Female Gothic. Ed. J. FLEENOR. Montreal: Eden. 123-137.

STEPTO, R. 1994. "Intimate Things in Place: A Conversation with Toni Morrison." Conversations with Toni Morrison. Ed. D. TAYloR-GuTHRIE. Jackson: Mississippi UP. 10-29.

TATE, C. 1994. "Toni Morrison.” Conversations with Toni Morrison. Ed. D. TAYloRGUTHRIE. Jackson: Mississippi UP. 156-170.

TAYLOR-GuthrIE, D., ed. 1994. Conversations with Toni Morrison. Jackson: Mississippi UP.

VAllejo Álvarez, M. 1998. La identidad afroamericana y la victimización femenina en la narrativa de Toni Morrison. Madrid: Universidad Complutense. 16 Feb. 2012.

http://eprints.ucm.es/tesis/19972000/H/3/H3074901.pdf.

Wilentz, G. 1997. "An African-Based Reading of Sula." Approaches to Teaching the Novels of Toni Morrison. Eds. N. MCKaY \& K. EARLE. New York, NY: MLA. 127-134.

Williams, A. 1995. Art of Darkness: A Poetics of Gothic. Chicago: Chicago UP. 


\section{Please use this identifier to cite or link to this item:}

http://hdl. handle. net/10835/2078

Full metadata record

DC Field

Value

Language

dc.contributor.author López Ramírez, Manuela

dc.date.accessioned 2013-04-04T12:13:51Z

dc.date.available 2013-04-04T12: 13:51Z

dc.date.issued 2012

dc.identifier.issn $1578-3820$

dc.identifier.uri http: //hdl.handle.net/10835/2078

dc.description.abstract Through Sula (the main character of Toni

es_ES

Morrison's eponymous novel), Morrison

reinterprets the concept of the Dark Lady of

the traditional Gothic romance. She is a demonic female, who de fi es the Law of the

Father in her search for identity. As the embodiment of subversion, she becomes the "village witch", the symbolic expression of the African community's confrontation with evil. In fact, through Sula, Morrison re fl ects intensively on evil. The demonic female comes to be a scapegoat, the target of the black community's social frustrations. Sula is a modern Dark Lady with a radical power of self-creation and self-af fi rmation.

dc.publisher Universidad de Almería.

es_ES

dc.source Odisea : Revista de Estudios Ingleses.

es_ES

Número 13, Enero-Diciembre 2012

dc.subject Dark Lady

es_ES

dc.subject Gothic

es_ES

dc.subject Transggresion

es_ES

dc.subject Black community

es_ES

dc.subject Evil

es_ES

dc.subject Patriarchal

es_ES

dc.subject Mujer oscura

es_ES 
dc.subject Gótico

es_ES

dc.subject Trasgresión

es_ES

dc.subject Comunidad negra

es_ES

dc.subject Mal

es_ES

dc.subject Patriarcal

es_ES

dc.title Sula, a dark lady.

es_ES

dc.title.alternative Sula, una mujer oscura.

es_ES

dc.type info: eu-repo/semantics/article

es_ES

dc.relation.publisherversion http://www.ual.es/odisea/Odisea13_Lopez.pdf es_ES dc.rights.accessRights info: eu-repo/semantics/openAccess

es_ES

Appears in Collections: Odisea : Revista de Estudios Ingleses.

Número 13, Enero-Diciembre 2012 